University of Wollongong

Research Online

Faculty of Law, Humanities and the Arts Papers (Archive)

Faculty of Arts, Social Sciences \& Humanities

$1-1-2013$

Becoming Buddhist: Experiences of Socialization and Self-Transformation in Two Australian Buddhist Centres

Josip Matesic

University of Wollongong, jm114@uowmail.edu.au

Follow this and additional works at: https://ro.uow.edu.au/lhapapers

Part of the Arts and Humanities Commons, and the Law Commons

Research Online is the open access institutional repository for the University of Wollongong. For further information contact the UOW Library: research-pubs@uow.edu.au 


\title{
Becoming Buddhist: Experiences of Socialization and Self-Transformation in Two Australian Buddhist Centres
}

\author{
Abstract \\ Review of: Glenys Eddy: Becoming Buddhist: Experiences of Socialization and Self-Transformation in Two \\ Australian Buddhist Centres. London, U.K.; New York, U.S.A: Continuum, 2012; pp. xiii + 220. \\ Keywords \\ two, becoming, australian, buddhist, centres, experiences, socialization, self, transformation \\ Disciplines \\ Arts and Humanities | Law \\ Publication Details \\ Matesic, J. 2013, 'Becoming Buddhist: Experiences of Socialization and Self-Transformation in Two \\ Australian Buddhist Centres', Journal of Religious History, vol. 37, no. 2, pp. 286-287.
}




\section{GLENYS EDDY: Becoming Buddhist: Experiences of Socialization and Self- Transformation in Two Australian Buddhist Centres. London, U.K.; New York, U.S.A: Continuum, 2012; pp. xiii + 220.}

Glenys Eddy's Becoming Buddhist: Experiences of Socialization and Self-Transformation in Two Australian Buddhist Centres (Continuum, 2012) aims to articulate what it means to be a Western Buddhist according to two Buddhist centres located in Sydney, Australia. These two centres are the Blue Mountains Insight Meditation Centre (BMIMC) and the Vajrayana Institute (VI). Eddy examines the engagement and change in students, practitioners and adherents at these two centres via the religious activity that is offered. The socialisation process is explored from initial apprehension and comprehension, to final commitment.

Eddy establishes early the theoretical and methodological background to the project, and she also acknowledges possible personal biases. A part of the first chapter is devoted to examining theories associated with understanding religious change. This section is covered quite well with discussion of John Lofland and Norman Skonovd's experimental motif, Peter Berger's phenomenological sociology along with Melford Spiro's model of internalisation. This section is also the beginning of a trend that exists throughout the book, as it is introducing theorists solely by their surname. This shortcoming aside, Eddy details her methodologies: participant observation, interviews, and access to teaching material. Eddy also details problems that she encountered, some of which were quite practical such as BMIMC and VI holding meditation classes on the same night, thus making participant observation only possible at one place. At the end of this first chapter, it is good to see that Eddy openly acknowledges her own changes and growing sympathy to Buddhism and Buddhists, while mentioning her own religious background and past.

From Chapter 2 to Chapter 5, the first two chapters focus on BMIMC and the latter two chapters focus on VI. Chapter 2 focuses on the instruction and practice given at BMIMC. Eddy spends a great deal of time in this chapter trying "to understanding the relationship between experiential states and their interpretation according to Buddhist doctrine by both practitioners and the researcher" (p. 32). A great amount of detail is given about a number of weekend retreats that were taken during the field work for the project. The amount of space devoted to this, along with the corresponding appendices which give the timetable for the 
respective weekend retreats (Appendices 2-5). While they seem repetitive, they make the reader feel as if they were at the retreat.

Chapter 3 examines the changes that occurred as people adopted and began to practice the vipassana meditation taught at BMIMC, and whether they combined it with any other techniques, and what the results were. It is here that transcript of the interviews start to become a common feature of the book. Perhaps as a result, the chapter focusses on how people have changed, what they did and do for this to happen, and what changes they have noticed.

Eddy sets out in the beginning of the fourth chapter that the chapter will focus on how students and practitioners "come to acquire a sense of reality from the perspective of the FPMT" (p. 107). The FPMT refers to the Foundation for the Preservation of the Mahayana Tradition, a worldwide Gelugpa Tibetan organisation. The chapter examines how people who go to VI learn about (Tibetan) Buddhism through meditation, teaching, and various rituals. Eddy admits that someone unfamiliar with the basics of Buddhism may find the rituals and symbolism at VI to be awkward and it is unclear how a Westerner would initially relate to this Tibetan worldview (p. 123).

Chapter 5 in part gives a brief overview of the tantric practices at VI but Eddy points out that this is largely a semi-secret practice among the more advanced students, and generally they do not discuss their involvement in tantra as it is considered to be a private matter (p. 137).

The final chapter aims to explore "the entire socialization and commitment process as it is experienced by affiliates of both Centres" (p. 167). It is in this last chapter that Eddy's book really comes together. All the pieces of the puzzle join. Through an examination of the interviews from participants, Eddy concludes that in the majority of cases, it is through a steady gradual process, with two or three periods of increasing involvement, results in the decision to either: commit to Buddhism, recognise that one is already committed, or continue to seek.

In an overview of the book, there are a number of features that are to be commended, but there are some that need to be noted. The overall structure of the chapters was good and logical. The glossary of Buddhist terms at the beginning of the book was good, however the 
glossary could have been more detailed with more entries. The appendices were terrific, providing in part the timetables of the various retreats that Eddy did as part of her field work. The appendices also gave basic demographic information about the people interviewed by Eddy without compromising their privacy. Typographic errors were few, a sign of good and detailed production. A common shortcoming throughout the book however was that when discussing the various academic literature, the authors were only ever referred to by their surname. This was a slight annoyance. 